Eur J Clin Chem Clin Biochem

1995; 33:53-58

(C) 1995 Walter de Gruyter \& Co.

Berlin - New York

\title{
A Sensitive Time-Resolved Immunofluorometric Assay for the Measurement of Apolipoprotein B in Cerebrospinal Fluid. Application to Multiple Sclerosis and Other Neurological Diseases
}

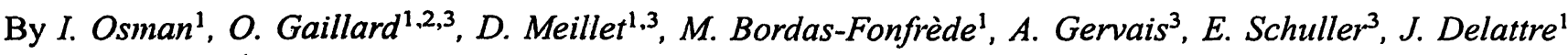 \\ and $A$. Legrand ${ }^{4}$ \\ ${ }^{1}$ Laboratoire de Biochimie, ${ }^{2}$ Laboratoire d'Immunochimie, ${ }^{3}$ Laboratoire de Neuroimmunologie - \\ INSERM U 134, Hôpital de la Salpêtrière, Paris, France \\ ${ }^{4}$ Laboratoire de Biochimie, Hôpital de Bicêtre, Le Kremlin-Bicêtre, France
}

(Received June 20/November 7, 1994)

Summary: Although low density lipoprotein receptors have been described on oligodendrocytes, apolipoprotein B was thought to be absent or present in only very small amounts in cerebrospinal fluid (CSF). Several immunoassays have been used for the measurement of apolipoprotein B in serum. However, the majority of methods cannot be used to measure small amounts of apolipoprotein B in CSF. In this study, we describe a highly sensitive time resolved immunofluorometric assay (TR-IFMA) using europium as label (detection limit: $0,3 \mu \mathrm{g} / \mathrm{l}$ ). The reliability of the TR-IFMA for the measurement of apolipoprotein B was first studied in serum. Serum and CSF apolipoprotein $B$ concentrations were then determined in subjects free of neurological disorders and in patients with multiple sclerosis. Local intrathecal apolipoprotein B synthesis was calculated. Although the high sensitivity of the TRIFMA allowed low amounts of apolipoprotein B in CSF to be detected $(0.11 \pm 0.06 ; 0.12 \pm 0.06 \mathrm{mg} / \mathrm{l}$ in controls and multiple sclerosis patients, respectively), no apolipoprotein B could be detected in CSF by electroimmunodiffusion. As suggested by the blood/CSF apolipoprotein B ratio (about 6000), no apolipoprotein B synthesis was observed by both using apolipoprotein $\mathrm{B}$ index and formula. This indicates its probable serum origin. Moreover, there was no difference between controls and multiple sclerosis patients in CSF, serum, blood/CSF, index, and local intrathecal apolipoprotein B synthesis. Finally, these results suggest that the role of apolipoprotein B in lipid transport in the central nervous system may be questionable.

\section{Introduction}

The central nervous system, together with peripheral neural tissue, possesses a lipid transport system involving apolipoproteins which is responsible for maintaining cholesterol and lipid homeostasis (1). Multiple sclerosis is a neurological disease characterized by primary destruction of myelin and followed by marked alterations of myelin cholesterol and lipid metabolism (2). Apolipoprotein $B$ is involved in the mediation of lipoprotein binding, uptake and cholesterol delivery via low density lipoprotein (LDL) receptors. Although LDL receptors have been described on oligodendrocytes (1), apolipoprotein B was thought to be absent $(1,3)$ or present in only very small amounts in cerebrospinal fluid (CSF) (4) with the exception of cerebrotendinous xanthomatosis (5).

Most immunoassays have been used for the measurement of apolipoprotein B in serum (6-9). However, the most suitable methods, immunoturbidimetric assay and immunonephelometric assay, cannot be used to measure very small amounts of apolipoprotein B in CSF. Enzyme linked immunosorbent assays (ELISA) and radioimmunoassay (RIA) are sensitive, but the linear working range of the curve of ELISA is small $(10,11)$ and RIA requires a radiolabelling license (12). To measure apolipoprotein B in CSF, we have developed a very sensitive 
method: time-resolved immunofluorometric assay (TRIFMA) using europium as label. The value of TR-IFMA for the measurement of proteins present in small amounts in CSF has been reported elsewhere (13-15). The reliability of TR-IFMA for the measurement of apolipoprotein B was first studied in serum. A comparative study was then performed with an electroimmunodiffusion on serum and CSF samples. Because usual techniques are not sensitive enough to measure small amounts of apolipoprotein B, a comparative study was performed immunonephelometrically with serum samples from normolipidaemic and dyslipidaemic subjects. CSF and serum apolipoprotein B concentrations were then determined in subjects free of neurological disorders and in patients with multiple sclerosis. Local intrathecal apolipoprotein B synthesis was calculated.

\section{Materials and Methods}

\section{Study population}

\section{Three groups of patients were studied}

The first group (group A) consisted of 24 controls ( 7 women, 17 men, average age: $42 \pm 13$ years, range: $22-63$ ) to determine the reference range of apolipoprotein B in CSF. These samples were then used in a comparison between TR-IFMA and electroimmunodiffusion. None of the controls had an increased immunoglobulin $\mathrm{G}$ (IgG) index or an oligoclonal band in their CSF, and none had evidence of active demyelinating disease. The integrity of the blood-brain barrier was assessed by measuring albuminorachia (serum albumin: $43164 \pm 5466 \mathrm{mg} / \mathrm{l}$; CSF albumin: $228.5 \pm 78.4$ $\mathrm{mg} / \mathrm{l})$. None of the controls had dyslipoproteinaemia (cholesterol: $4.65 \pm 1.98 \mathrm{mmol} / \mathrm{l}$; triacylglycerols: $1.56 \pm 0.37 \mathrm{mmol} / \mathrm{l})$.

The second group (group B) was composed of 30 multiple sclerosis patients (24 women, 6 men, average age: $39 \pm 15$, range: $29-65$ ) with an increased IgG index and oligoclonal banding in CSF. None had important blood-CSF barrier damage (serum albumin: 42530 $\pm 6221 \mathrm{mg} / \mathrm{l}$; CSF albumin: $250.0 \pm 98.0 \mathrm{mg} / \mathrm{l}$ ) or dyslipoproteinaemia (cholesterol: $4.80 \pm 0.2 \mathrm{mmol} / \mathrm{l}$; triacylglycerols: 1.76 $\pm 0.23 \mathrm{mmol} / \mathrm{l})$.

Paired serum and CSF samples were collected during a single $24 \mathrm{~h}$ period and stored at $-70^{\circ} \mathrm{C}$ until analysis.

The third group (group C) consisted of 94 subjects, whose sera were used for an intermethod comparison of apolipoprotein B values in serum between TR-IFMA and immunonephelometry. Thirtyseven subjects with a mean ( \pm standard deviation) cholesterol concentration of $5.18 \pm 0.63 \mathrm{mmol} / \mathrm{l}$ (range: $4.10-5.90 \mathrm{mmol} / \mathrm{l}$ ) and triacylglycerol concentrations of $1.02 \pm 0.29 \mathrm{mmol} / \mathrm{l}$ (range: $0.48-1.35 \mathrm{mmol} / \mathrm{l}$ ) formed the normolipidaemic subgroup. Twenty-five subjects with mean cholesterol concentrations of 7.49 $\pm 1.10 \mathrm{mmol} / \mathrm{l}$ (range: $6.20-10.80 \mathrm{mmol} / \mathrm{l}$ ) and triacylglycerol concentrations of $1.10 \pm 0.21 \mathrm{mmol} / 1$ (range: $0.71-1.40 \mathrm{mmol} / \mathrm{l}$ ) formed the hypercholesterolaemic subgroup. Thirty-two subjects with a mean cholesterol concentration of $5.15 \pm 0.94 \mathrm{mmol} / \mathrm{l}$ (range: $2.80 \pm 6.50 \mathrm{mmol} / \mathrm{l}$ ) and triacylglycerolaemia of 3.02 $\pm 1.36 \mathrm{mmol} / 1$ (range: $1.61-7.36 \mathrm{mmol} / \mathrm{l}$ ) formed the hypertriacylglycerolaemic subgroup. Sera were stored at $4^{\circ} \mathrm{C}$ for $24 \mathrm{~h}$ until being assayed.

\section{Measurement of apolipoprotein B by TR-IFMA}

\section{Apparatus}

We used a time-resolved fluorometer (1230 Arcus $^{\mathrm{TM}}$ ), a 12-well aspirating-washing device (1296-024 Platewash), and an automated shaker (1296-001 Plateshake), all from Pharmacia (Uppsala, Sweden).

\section{Reagents}

We used a purified rabbit anti-human apolipoprotein B IgG antibody (Interservice B.M., Brazzaville, Bériin) in phosphate buffer (0.1 mol/l, $\mathrm{pH}$ 7.4). Delfia ${ }^{\mathrm{TM}}$ europium-labeling kits were purchased from Pharmacia. Each kit contains $0.2 \mathrm{mg}$ of labeling reagent $\left(N^{1}-(p\right.$-isothiocyanatobenzyl)-diethylenetriamine$N^{1}, N^{2}, N^{3}, N^{3}$-tetraacetate-europium), a $100 \mathrm{nmol} / 1$ europium standard, highly purified bovine serum albumin $(5 \mathrm{~g} / 1$ in Tris- $\mathrm{HCl} 50$ $\left.\mathrm{mmol} / 1, \mathrm{pH} \mathrm{7.8}, \mathrm{NaN}_{3}, 0.5 \mathrm{~g} / \mathrm{l}\right)$, stabilizer, and enhancement solution (per litre, $15 \mathrm{mmol}$ 2-naphthoyltrifluoroacetone, $50 \mathrm{mmol}$ tri$n$-octylphosphine oxide, $100 \mathrm{mmol}$ acetic acid, $6.8 \mathrm{mmol}$ potassium hydrogen phthalate, and $1.0 \mathrm{~g}$ of Triton X-100 detergent). PD10 columns were from Pharmacia.

\section{Buffers}

The labeling buffer was $50 \mathrm{mmol} / 1 \mathrm{NaHCO}_{3}, \mathrm{pH} 8.5$, containing $9 \mathrm{~g} / \mathrm{l} \mathrm{NaCl}$. The elution buffer was $50 \mathrm{mmol} / \mathrm{h}$ Tris- $\mathrm{HCl}, \mathrm{pH} 7.8$, containing $9 \mathrm{~g} / \mathrm{l} \mathrm{NaCl}$ and $0.5 \mathrm{~g} / 1 \mathrm{NaN}_{3}$. The coating buffer was $\mathrm{K}_{2} \mathrm{HPO}_{4}(50 \mathrm{mmol} / \mathrm{l}, \mathrm{pH} 8.5)$, and the saturation solution was 50 $\mathrm{mmol} / 1 \mathrm{NaH}_{2} \mathrm{PO}_{4}, 2 \mathrm{H}_{2} \mathrm{O}, 60 \mathrm{~g} / \mathrm{l}$ sorbitol and $5 \mathrm{~g} / 1$ bovine serum albumin. The dilution buffer was $50 \mathrm{mmol} / \mathrm{l}$ Tris- $\mathrm{HCl}, \mathrm{pH} 7.75$, $9 \mathrm{~g} / \mathrm{l} \mathrm{NaCl}, 5.0 \mathrm{~g} / \mathrm{l}$ bovine serum albumin, $0.5 \mathrm{~g} / 1$ bovine $\gamma$-globulin, $100 \mathrm{mg} / 1 \mathrm{Tween} 40$, and $20 \mu \mathrm{mol} / /$ di-ethylene-triaminopentaacetic acid. The washing solution was $100 \mathrm{mmol} / \mathrm{l}$ Tris $-\mathrm{HCl}, \mathrm{pH} 7.75$, with $3 \mathrm{~g} / 1$ Tween 20.

\section{Standard}

Human serum standard OKTL (Behring, Marburg, Germany), which has an apolipoprotein B concentration of $1.15 \mathrm{~g} / \mathrm{l}$, was diluted with buffer to obtain six standard concentrations.

\section{Labeling}

Purified rabbit anti-human apolipoprotein B IgG antibodies (150 $\mu l)$ were loaded onto a PD 10 column rinsed with labeling buffer. Fractions of $500 \mu \mathrm{l}$ were collected and protein absorbance was measured at $280 \mathrm{~nm}$ with an Ultraspec II (Pharmacia). The fraction corresponding to peak absorbance (about $2.5 \mathrm{ml}$ of elution buffer) containing about $1.0 \mathrm{~g} / 1 \mathrm{IgG}$ (an absorbance value of 1.34 corresponding to $1 \mathrm{~g} / \mathrm{lgG})$. A volume of $250 \mu \mathrm{l}(0.25 \mathrm{mg} \mathrm{IgG})$ was added to $0.05 \mathrm{mg}$ of labeling reagent (containing the europiumchelate) and incubated overnight at room temperature with gentle stirring.

\section{Purification of europium-labeled IgG}

The preparation was purified by gel filtration through a PD-10 column and eluted with elution buffer. Ten $1-\mathrm{ml}$ fractions were collected and absorbance was read at $280 \mathrm{~nm}$. Fractions corresponding to peak IgG absorbance were pooled.

\section{Characterization of europium-labeled IgG}

The amount of europium-labeled antibody bound to anti-apolipoprotein B was determined by measuring europium fluorescence relative to that of the europium chloride standard $(100 \mathrm{nmol} / \mathrm{l})$. After addition of enhancement solution, the fluorescence of the europium-2-naphthoyl trifluoroacetone chelate was measured as counts per second in a time-resolved fluorometer. The protein content of the europium-labeled antibody was quantified after measuring absorbance at $280 \mathrm{~nm}$ as:

Protein $(\mathrm{mol} / \mathrm{l})=\mathrm{A}_{280}-(0.008 \times \mathrm{Eu}) \times 10^{6} / \mathrm{A} \times M_{\mathrm{r}}$ 
( $A_{280}$ : absorbance of eluted fraction at $280 \mathrm{~nm}, 0.008$ : absorbance of bound aromatic thiourea, Eu: amount of europium (mmol/l), A: absorbance of IgG (1.34), $M_{\mathrm{r}}$ : relative molecular mass of IgG $(160000))$.

The europium/protein ratio was used to calculate the conjugation yield ( 7 europium molecules per IgG molecule). The labeled antibody was stored with stabilizer to improve the stability of the europium-labeled IgG. There was no loss of immunoreactivity during six months of storage at $4^{\circ} \mathrm{C}$.

\section{Coating of microtitre plates}

Unlabeled anti-apolipoprotein B IgG was diluted in buffer to a final concentration of $100 \mathrm{mg} /$. Polystyrene microtitre plates (Microwell $^{\mathrm{TM}}$, Nunc Inc., Naperville, USA) were coated by adding 200 $\mu l$ of the antibody solution per well and incubating the plates for $1 \mathrm{~h}$ at $37^{\circ} \mathrm{C}$. The wells were then washed three times with $250 \mu \mathrm{l}$ of saturation solution per well to block non-specific binding sites, aspirated and used immediately.

\section{Immunoassay procedure}

Human serum standard dilutions were made in dilution buffer from $10^{-6}$ to $2.5 \times 10^{-2}$. Serum and CSF samples were also diluted in dilution buffer to $2.5 \times 10^{-5}$ and $10^{-1}$, respectively. Two hundred $\mu l$ of each dilution was placed in duplicate wells and incubated for $2 \mathrm{~h}$ at room temperature on an automated shaking device. The reaction was stopped by washing the wells six times with washing solution, using the 12-well aspirating-washing device. Europiumlabeled anti-apolipoprotein B antibody was diluted to a final concentration of $250 \mu \mathrm{g} / 1$ in assay buffer, then $200 \mu \mathrm{l}$ was added per well and incubated for $1 \mathrm{~h}$ at room temperature with gentle shaking. The reaction was stopped as described above. The amount of labeled antibody bound to apolipoprotein B was quantified by dissociating europium from the antibody with enhancement solution $(200 \mu \mathrm{l}$ per well), followed by $10 \mathrm{~min}$ incubation with shaking and a further $10 \mathrm{~min}$ without shaking. The fluorescence of europium - 2-naphthoyltrifluoroacetone acetate was measured as counts per second in the time-resolved fluorometer. The instrument's data-reduction program was used to calculate the concentration of apolipoprotein B in the samples.

\section{Criteria of reliability}

\section{Linearity}

The linearity of the method was determined using the human serum standard diluted to apolipoprotein B concentrations between 1.15 and $57500 \mu \mathrm{g} / \mathrm{l}$. Each dilution was assayed six times in three separate runs.

\section{Detection limit}

The lower detection limit of the assay was defined as the concentration corresponding to the mean plus 3 standard deviations of the zero standard fluorescence signal (for 15 replicates in 5 analytical runs).

\section{Precision}

The intra-assay precision of the TR-IFMA method was studied by analysing the human serum standard at three apolipoprotein $B$ concentrations $(11.5,115$ and $575 \mu \mathrm{g} / 1) 20$ times each. Inter-assay precision was studied by analysing control solutions at two apolipoprotein B concentrations (11.5 and $575 \mu \mathrm{g} / 1) 15$ times each over a period of three weeks.

\section{Intermethod comparison}

A comparative study was performed with an electroimmunodiffusion assay with serum and CSF samples for patients from groups $A$ and $B$, and with an immunonephelometric technique (BNA, Behringwerke, Marburg, Germany) with serum samples from normolipidaemic and dyslipidaemic subjects.

Immunoreactivity of anti-apolipoprotein B antibodies with apolipoprotein B in isolated LDL and serum

LDL of the density range of $1.03-1.05 \mathrm{~kg} / \mathrm{dm}^{3}$ was obtained by ultracentrifugation of serum from normolipidaemic subjects (16). Isolated $\mathrm{LDL}$ was dialyzed against dilution buffer ( $\mathrm{pH} 7.75)$. Apolipoprotein $\mathrm{B}$ in the isolated LDL fraction was then measured by immunonephelometry (apolipoprotein B: $0.9 \mathrm{~g} / \mathrm{l}$ ) and stored at $4{ }^{\circ} \mathrm{C}$ for $24 \mathrm{~h}$. Curves of fluorescence intensities versus dilutions of isolated LDL and human serum standard (apolipoprotein B: $1.15 \mathrm{~g} / \mathrm{l}$ ) were constructed. Their slopes were compared to test the immunoreactivity of the anti-apolipoprotein $B$ antibodies used in the TRIFMA.

\section{Comparison of dose-response curves for} apolipoprotein $B$ in serum and CSF

Dose-response curves (apolipoprotein B concentration versus fluorescence counts) were constructed for serum and CSF.

\section{Other assays}

Albumin and IgG were determined in serum and CSF by means of electroimmunodiffusion as previously described (17). Serum samples were analysed for cholesterol and triacylglycerols by enzymatic methods with a SMAC II-analyser ${ }^{\mathrm{TM}}$ (Bayer Diagnostics, Puteaux, France).

\section{Evaluation of intrathecal synthesis}

The blood/CSF ratio of apolipoprotein B was calculated. An index analogous to the CSF IgG index was calculated as follows: Apolipoprotein B index = (CSF apolipoprotein B/serum apolipoprotein $\mathrm{B}) /(\mathrm{CSF}$ albumin/serum albumin).

Local intrathecal apolipoprotein B synthesis was calculated using the formula of Schuller (18), as:

if CSF albumin $\leq 210 \mathrm{mg} /$, local intrathecal apolipoprotein B synthesis = CSF apolipoprotein B - 200;

if CSF albumin $>210 \mathrm{mg} / \mathrm{l}$, local intrathecal apolipoprotein B synthesis $=$ CSF apolipoprotein $\mathrm{B}-(200+(\{\mathrm{CSF}$ albumin $-210\} / 153) \times($ serum apolipoprotein B)). In this formula, 200 is the upper limit of normal filtration of apolipoprotein B and 153 the transudation equivalence of apolipoprotein $B$ related to its relative molecular mass (549000) comparatively to albumin transudation; $210 \mathrm{mg} / \mathrm{l}$ is the mean reference value of CSF albumin.

\section{Statistical analysis}

The serum apolipoprotein B concentrations obtained by TR-IFMA and immunonephelometry were compared using the Mann and Whitney non-parametric test. Intermethod comparisons were made by using the Spearman rank test and a regression line was plotted. 


\section{Results}

\section{Criteria of reliability}

\section{Linearity}

The method was linear for apolipoprotein B concentrations between $3 \mu \mathrm{g} / \mathrm{l}$ and $11500 \mu \mathrm{g} / \mathrm{l}$. In standard use, the calibration curve for the human serum standard can be established at apolipoprotein B concentrations from $3 \mu \mathrm{g} / \mathrm{l}$ to $1150 \mu \mathrm{g} / \mathrm{l}$ (fig. 1).

\section{Detection limit}

The lower detection limit of the TR-IFMA for apolipoprotein B was $0.3 \mu \mathrm{g} / \mathrm{l}$.

\section{Precision}

The within-run coefficients of variation (CVs) were $12.5 \%$ for $11.5 \mu \mathrm{g} / \mathrm{l}, 5.8 \%$ for $115 \mu \mathrm{g} / \mathrm{l}$ and $5.2 \%$ for 575 $\mu \mathrm{g} / \mathrm{l}$ apolipoprotein B. The between-run CVs were $15.2 \%$ for $11.5 \mu \mathrm{g} / \mathrm{l}$ and $8.2 \%$ for $575 \mu \mathrm{g} / \mathrm{l}$ apolipoprotein $\mathrm{B}$.

\section{Intermethod comparison}

No apolipoprotein B was detected in CSF by means of electroimmunodiffusion with a detection limit of $1 \mathrm{mg} / \mathrm{l}$. In serum, there was good positive agreement between TR-IFMA and electroimmunodiffusion in group $\mathrm{A}$ and $B(r=0.65 ; p<0.01)$. There was also good positive

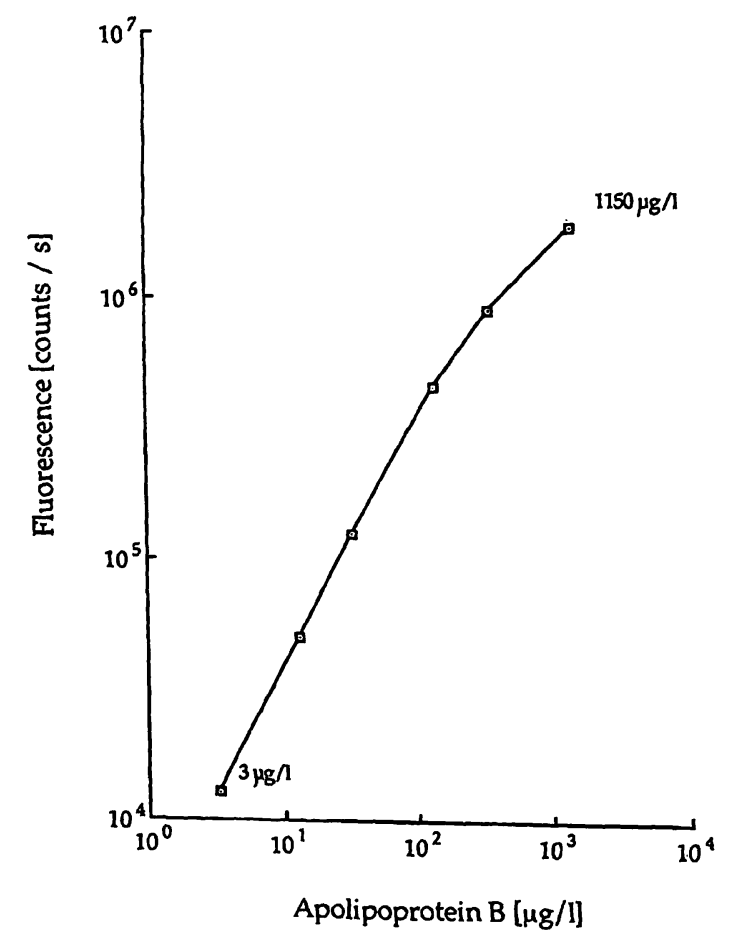

Fig. 1 Calibration curve for the measurement of apolipoprotein B by TR-IFMA - Serum standard OKTL (Behring, Marburg, Germany), apolipoprotein B: $1.15 \mathrm{~g} /$.

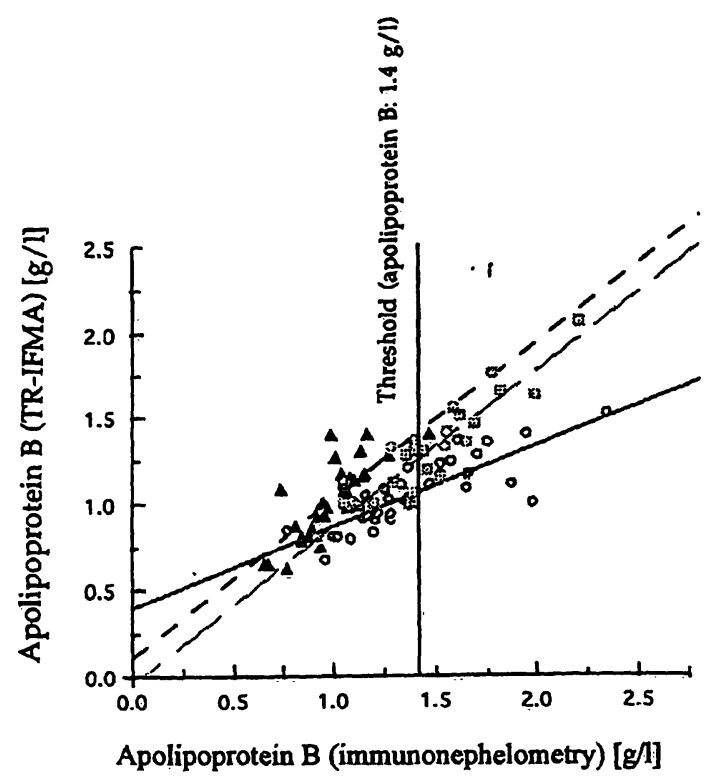

Fig. 2 Correlation between TR-IFMA and immunonephelometry for the measurement of apolipoprotein B in normolipaemic ( $\mathbf{A}$ ) $(y=0.93 x+0.10 ; \quad r=0.82), \quad$ hypercholesterolaemic ( $\square)$ $(y=0.47 x+0.40 ; r=0.82)$ and hypertriacylglycerolaemic subjects $(0)(y=0.91 x-0.04 ; r=0.91)$ (group $C)$.

agreement between TR-IFMA and immunonephelometric apolipoprotein $B$ values for all the subjects in group $C(p<0.001)$ and in each subgroup (normolipidaemic, hypercholesterolaemic and hypertriacylglycerolaemic) $(p<0.001)$ (fig. 2). The mean serum apolipoprotein B concentrations in normolipidaemic subjects were 1.02 $\mathrm{g} / \mathrm{l}$ and $1.01 \mathrm{~g} / \mathrm{l}$ by TR-IFMA and immunonephelometry, respectively. The mean apolipoprotein $B$ concentration in the subjects with hypercholesterolaemia was slightly lower by TR-IFMA than by immunonephelometry $(p<0.05)(1.27 \mathrm{~g} / 1$ and $1.44 \mathrm{~g} / \mathrm{l}$, respectively). The TRIFMA apolipoprotein B concentration was $15 \%$ lower than the immunonephelometric value for apolipoprotein B $<1.4 \mathrm{~g} / 1$ and $14 \%$ lower for apolipoprotein $\mathrm{B} \geq 1.4$ $\mathrm{g} / \mathrm{l}$. The mean apolipoprotein $\mathrm{B}$ concentration in the subjects with hypertriacylglycerolaemia was lower by TRIFMA than by immunonephelometry $(p<0.001)(1.03$ $\mathrm{g} / \mathrm{l}$ and $1.36 \mathrm{~g} / \mathrm{l}$, respectively). The TR-IFMA apolipoprotein $B$ concentration were $27 \%$ lower than immunonephelometric values for apolipoprotein $B<1.4 \mathrm{~g} / \mathrm{l}$ and $42 \%$ lower for apolipoprotein $B \geq 1.4 \mathrm{~g} / \mathrm{l}$.

Immunoreactivity of the anti-apolipoprotein $B$ antibodies with apolipoprotein B in isolated LDL and serum

The slopes of the curves for fluorescence counts versus dilutions of isolated LDL and human serum standard OKTL were similar at apolipoprotein B concentrations from 225 to $9000 \mu \mathrm{g} / 1$. The dose-response curves for 
serum and CSF apolipoprotein B concentrations were identical (data not shown).

\section{CSF and serum apolipoprotein $B$} concentrations, apolipoprotein B blood/CSF ratio, index and local intrathecal synthesis in groups A and B

Table 1 gives the means and standard deviations for the serum and CSF apolipoprotein B and albumin concentrations and the apolipoprotein B blood/CSF ratio, index and local intrathecal synthesis in groups $A$ and $B$. There was a highly significant correlation between CSF apolipoprotein $B$ and CSF albumin $(r=0.79 ; p<0.001)$ in group $A$ and $(r=0.65 ; p<0.005)$ in group $B$. There was also a significant correlation between CSF apolipoprotein $B$ and albumin quotient $(r=0.77$ in group $A$ and $r=0.71$ in group $B ; p<0.001$ ). There were no differences between the two groups in any of the quantities studied.

\section{Discussion}

Several immunoassays have been used for the measurement of apolipoprotein B in serum (19). These assays are usually not sensitive enough for the measurement of small amounts of apolipoprotein B in other body fluids such as CSF. In addition, the most suitable for routine use, immunoturbidimetry and immunonephelometry, are subject to interference by turbidity in the sample (20).

In order to measure apolipoprotein B in CSF, we developed a highly sensitive method, TR-IFMA. Reliability was satisfactory. The sensitivity of the TR-IFMA (0.06 $\times 10^{-3} \mu \mathrm{g} /$ well $)$ was better than that of RIA $(0.3-10$ $\times 10^{-3} \mu \mathrm{g} /$ well $)$ and ELISA $\left(0.1-0.5 \times 10^{-3} \mu \mathrm{g} /\right.$ well) (21), owing to both the retained immunoreactivity of the chelate-labelled antibodies and the highly sensitive time-resolved fluorescent detection method for enhanced chelate fluorescence (22). The working range was large, contrary to ELISA (11), and within- and between-run precision was good. A correlation was obtained between TR=IFMA and electroimmunodiffusion in serum and immunonephelometry for serum apolipo- protein B concentrations in group C. The mean apolipoprotein B concentrations obtained with TR-IFMA matched those obtained by immunonephelometry in the normolipidaemic and hypercholesterolaemic subgroups. The higher values obtained by immunonephelometry in the hypertriacylglycerolaemic subgroup could be related to the difference observed between one-site (nephelometry) and two-site (TR-IFMA) assays (23). These higher values could be due to the sensitivity of the nephelometric method to the size of the analyte, owing to differences in light scattering (24). Indeed, the measurement of apolipoprotein B can be inaccurate in samples containing large triacylglycerol-rich particles (12). The overestimation of apolipoprotein B by immunonephelometry in hypertriacylglycerolaemic serum is overcome by TR-IFMA which, by measuring fluorescence, is independent of sample turbidity (25).

The equal immunoreactivity of the anti-apolipoprotein B antibodies with apolipoprotein B in different forms (serum and isolated LDL), and the equal dose-response curves for serum and CSF apolipoprotein B, makes this method well adapted to the quantification of apolipoprotein B in CSF.

The sensitivity of TR-IFMA was sufficient to detect small amounts of apolipoprotein B in CSF from all the patients studied. No apolipoprotein B was detected in CSF by electroimmunodiffusion (detection limit: $1 \mathrm{mg} / \mathrm{l})$. These observations are in agreement with reports by Roheim et al. (3) and Pitas et al. (1). Using a sensitive ELISA, Carlson et al. also reported the presence of apolipoprotein B in CSF (4). The higher CSF apolipoprotein B concentrations described by Carlson $(0.77 \pm 3.4 \mathrm{mg} / \mathrm{l}$ versus $0.12 \pm 0.06 \mathrm{mg} / \mathrm{l}$ in our study) could be explained by difference in the patients studied. Indeed, these authors studied only neurological patients with large variations in CSF albumin, i. e. with bloodCSF barrier damage. No differences were observed in serum and in CSF apolipoprotein B concentrations between controls and multiple sclerosis patients, none of whom had increased blood-CSF barrier permeability. As Carlson reported, CSF apolipoprotein B concentrations were several orders of magnitude lower than the corresponding serum concentrations: the blood/CSF ratios

Tab. 1 Concentrations of quantities studied in control subjects (group A) and multiple sclerosis patients (group B)

\begin{tabular}{|c|c|c|c|c|c|c|}
\hline & \multicolumn{2}{|c|}{ Serum apolipoprotein B (mg/l) } & \multicolumn{4}{|c|}{ CSF apolipoprotein B (mg/l) } \\
\hline & TR-IFMA & EID & TR-IFMA & EID & Blood/CSF ratio & Index \\
\hline $\begin{array}{l}\text { Group A } \\
\text { Group B }\end{array}$ & $\begin{array}{l}934 \pm 180^{*} \\
886 \pm 219\end{array}$ & $\begin{array}{l}1149 \pm 298 \\
1387 \pm 456\end{array}$ & $\begin{array}{l}0.11 \pm 0.06 \\
0.12 \pm 0.06\end{array}$ & $\begin{array}{l}<1 \\
<1\end{array}$ & $\begin{array}{l}5920 \pm 1751 \\
6928 \pm 3205\end{array}$ & $\begin{array}{l}0.31 \pm 0.19 \\
0.34 \pm 0.21\end{array}$ \\
\hline
\end{tabular}

\footnotetext{
* Mean \pm standard deviation
} 
were about 6000 in both controls and multiple sclerosis patients. As presumed from these very high blood/CSF ratios, no apolipoprotein $B$ intrathecal synthesis was found by determination of both apolipoprotein $B$ index and local intrathecal synthesis in either group A or B. Moreover, the CSF apolipoprotein B concentrations showed a good correlation with the albumin quotient and the albumin level in CSF, indicating that the small amounts of apolipoprotein B in CSF are presumably of serum origin. It is noteworthy the Blue et al. found no apolipoprotein B synthesis in the rooster brain (26).

The excellent reliability of this technique, particularly its high sensitivity, makes it suitable for the measure- ment of apolipoprotein B in CSF and other fluids containing very low concentrations of apolipoprotein $B$. Moreover, a very small volume of CSF $(20 \mu \mathrm{l})$ is required. The very small amounts of apolipoprotein B in CSF indicate its probable serum origin, while the lack of differences between the controls and multiple sclerosis patients calls into question the role of this apolipoprotein in lipid transport in the central nervous system.

\section{Acknowledgement}

We thank H.J. Parra for useful advice, V. Frey-Fressart for isolation of LDL and M. C. Esposito for preparation of the manuscript.

\section{References}

1. Pitas RE, Boyles JK, Lee SH, Hui D, Weisgraber KH. Lipoproteins and their receptors in the brain. J Biol Chem 1987; 262:14352-60.

2. Gelman BB, Rifai N, Christenson RH, Silverman LM. Cerebrospinal and plasma apolipoproteins in patients with multiple sclerosis. Am Clin Lab Sci 1988; 18:46-52.

3. Roheim PS, Carey M, Forte T, Vega GL. Apolipoproteins in human cerebrospinal fluid. Proc Natl Acad Sci USA 1979; 76:4647-69.

4. Carlson J, Armstrong VW, Reiber H, Felgenhauer K, Seidel D. Clinical relevance of the quantification of apolipoprotein $\mathrm{E}$ in cerebrospinal fluid. Clin Chim Acta 1991; 196:167-76.

5. Salen G, Berginer V, Shore V, Horak I, Tint S et al. Increased concentrations of cholestanol and apolipoprotein B in the cerebrospinal fluid of patients with cerebrotendinous xanthomatosis. N Eng J Med 1987; 316:1233-38.

6. Havekes L, Hemmilä J, De White E. Determination of low density lipoprotein in plasma as measured by radial immunodiffusion and rocket immunoelectrophoresis. Clin Chem 1981; 27:1829-33.

7. Fruchart JC, Desreumaux C, Dewailly P, Sezille G, Jaillard J, Carlier $\mathrm{Y}$ et al. Enzyme-immunoassay for human apolipoprotein $B$, the major protein moiety in low density and very low density lipoprotein. Clin Chem 1978; 24:455-9.

8. Rifai N, King ME. Immunoturbidimetric assays of apolipoproteins A, AI, AII and B in serum. Clin Chem 1986; 32:957-61.

9. Ballantyne FC, Williamson J, Shapiro D, Caslake MJ, Perry B. Estimation of apolipoprotein $B$ in man by immunonephelometry. Clin Chem 1978; 24:788-92.

10. Labeur C, Shepherd J, Rosseneu M. Immunological assays of apolipoproteins in plasma: methods and instrumentation. Clin Chem 1990, 36:591-7.

11. Rosseneu M, Vercaemst R, Steinberg KK, Cooper GR. Some considerations of methodology and standardization of apolipoprotein B immunoassays. Clin Chem 1983; 29:427-33.

12. Adolphson J, Albers JJ. Comparison of two commercial nephelometric methods for apoprotein A-I and apoprotein B with standardized apoprotein A-I and radioimmunoassays. J Lipid Res 1989; 30:597-606.

13. Meillet D, Bélec L, Schuller E, Delattre J. Time-resolved fluoroimmunoassay of $\beta 2$-microglobulin in serum and cerebrospinal fluid. Clin Chem 1992; 39:552-3.

14. Gaillard O, Meillet D, Diemert MC, Musset L, Delattre J, Schuller E, Galli J. Time-resolved immunofluorometric assay of complement C3. Application to cerebrospinal fluid. Clin Chem 1993; 39:309-12.

15. Gaillard O, Meillet D, Gervais A, Delattre J, Galli J, Schuller E. Measurement of lipoprotein (a) in human cerebrospinal spinal fluid by a highly sensitive time-resolved immunofluorometric assay. Clin Chem 1994; 40:1975-6.

16. Havel RJ, Eder HA, Bragdon JH. The distribution of ultracentrifugaly separated lipoproteins in human serum. J Clin Invest 1955; 34:1345-53.

17. Schuller E, Tömpe L. Electroimmunodiffusion of IgG heavĩy chains in nanogram quantities with a carboxymethyl-cellulose agarose gel. Clin Chim Acta 1974; 54:145-56.

18. Schuller E, Benabdallah S, Sagar H, Reboul J, Tömpe L. IgG synthesis within the central nervous system: comparison of 3 formulae. Arch Neurol 1987; 44:600-4.

19. Sniderman A, Shapiro S, Marpole D, Skinner B, Teng B, Kwiterovich $\mathrm{PO}$ et al. Association of coronary atherosclerosis with hyperapobetalipoproteinemia (increased protein but normal cholesterol levels in human plasma low density $(\beta)$ lipoproteins). Proc Natl Acad Sci USA 1980; 77:604-8.

20. Walmsley TA, Grant George PM. Effect of plasma triglyceride concentration on the accuracy of immunoturbidimetric assays of apolipoprotein B. Clin Chem 1991; 37:748-53.

21. Bury J, Rosseneu M. Apolipoprotein quantitation by ELISA: technical aspects and clinical applications. Rev Immunoassay Tech 1988; 1:1-25.

22. Hemmilä I, Dakubu S, Mukkala VM, Siitari H, Lövgren T. Europium as a label in time-resolved immunofluorometric assays. Anal Biochem 1984; 135:335-41.

23. Keßler A, Schumacher M, Wood WG. Immunoluminometric assays for the quantification of apolipoproteins A-I, B, CII, apolipoprotein (a) and lipoprotein (a). Eur J Clin Chem Clin Biochem 1994; 32:127-35.

24. Wood WG, Steinhoff J, Fricke H. Relative molecular mass influences the results obtained when determining urinary proteins by laser nephelometry. J Immunol Meth 1990; 131:151-2.

25. Soïni E, Kojola $\mathrm{H}$. Time-resolved fluorometer for lanthanide chelates. A new generation of non isotopic immunoassays. Clin Chem 1983; 29:65-8.

26. Blue ML, Protter AA, Williams DL. Biosynthesis of apolipoprotein B in rooster kidney, intestine, and liver. J Biol Chem 1980; 255:10048-51.

Dr. Olivier Gaillard

Laboratoire d'Immunochimie

Hôpital de la Salpêtrière

47, Bd. de l'Hôpital

F-75651 Paris Cédex 13 